\title{
Teacher Perceptions of the Effectiveness of Using Handheld Devices in Saudi EFL Classroom Practices
}

\author{
https://doi.org/10.3991/ijet.v15i22.16689 \\ Sami Al-Mubireek \\ Imam Abdulrahman Bin Faisal University, Dammam, Saudi Arabia \\ smubireek@iau.edu.sa
}

\begin{abstract}
This study aims to investigate the effectiveness of using handheld devices such as smartphones and tablets for language teaching purposes (MobileAssisted Language Learning, or MALL). A questionnaire with a comment section was distributed in order to investigate EFL teachers' perceptions on including or excluding smartphones and tablets in the EFL learning process. Data were collected through a 5-likert scale questionnaire in a leading Saudi university. The findings revealed that the majority of teachers claimed to hardly ever use Android System Phones or iPhones (iOS System), Android tablets or iPads (iOS System) in classroom teaching. Importantly, the study found out that there is a statistically significant difference between male and female teachers in terms of which smart device operating system was reported being used. Within the few participants who employed technology, it was found that teachers with less teaching experience were more open to using technological devices in classroom. In addition, the findings showed that a significant number of teachers admitted to rarely using handheld devices in teaching reading, writing, listening, grammar or playing language-learning games. However, the majority of teachers said they sometimes used applications to assign online exercises, share information about the course, provide visual aids, develop the learners' speaking skills or as a translation tool. Moreover, teachers claimed to employ these devices frequently to teach vocabulary through visual aids when teaching. Teachers also rely heavily on these devices to communicate with students via social networks, and to access textbooks. Overall, teachers did not effectively integrate MALL into completing classroom language-learning activities or practicing language functions or skills.
\end{abstract}

Keywords-MALL, instructional technology, smart devices, operating systems

\section{Introduction}

Unprecedentedly rapid developments in technology have changed how work is conducted in every sector of society in recent decades. The field of education has been no exception. Educators, administrators and policy makers have all promoted the use of recent technologies in their practices. Nearly all students use smartphones, tablets and computers outside the classroom for common purposes such as social networking and accessing web-based resources. Educators and EFL researchers have not ignored the prominent role of such devices in the life of teachers and students. These devices have 
already revolutionized the field of computing and communication in general. They can offer a wide variety of tools and applications for various purposes.

Handheld devices are being utilized increasingly in schools and universities for multiple purposes. Some researchers have predicted that the utilization of these devices will have significant effects on instructional practices [1]. Though the integration of technology into education has changed the dynamics of language learning, policies should be designed to meet the needs of the current generation of teachers and learners. It is, therefore, essential that attitudes to changing classroom practices are investigated to provide a stronger basis for implementing technology effectively in the classroom.

\subsection{Objectives and questions of the study}

This study aims to investigate the effectiveness of using handheld devices as educational tools. It seeks to explore how frequently ESL teachers report incorporating such devices in teaching. In addition, it aims to find out what purposes such devices are used for in teaching and what promotes or hinders teachers from using such devices in teaching. Based on these objectives, the study aims to answer the following questions:

1. How frequently do ESL teachers use handheld devices in teaching?

2. What are the purposes of using handheld devices in terms of teaching?

3. What are the factors that promote or hinder using handheld devices in teaching?

\subsection{Significance of the study}

This study sheds light on the teacher motivations that hinder or promote the use of these technologies in teaching. It scrutinizes the teachers' point of view regarding the obstacles that prevent using handheld devices. This may provide possible solutions for promoting using such devices in teaching. The findings of this study also provide valuable insight into a particular educational context, namely higher education in Saudi Arabia. In addition, it may contribute to more effective teacher training and implementation of learning technology policies.

In recent years, the Saudi Ministry of Education has engaged in several initiatives to promote and implement digital learning in schools and universities. The present study explores and examines the implementation of one aspect of modern technology in Saudi EFL classes. The findings of this study will likely be of use to educational policymakers and complement future studies regarding the extent to which technology is being utilized in universities and how this can be done more effectively.

\subsection{Literature review}

Many studies have been conducted in order to explore the role of modern technology in EFL classrooms. Much research has particularly focused on the use of smartphones, tablets and computers. Despite many years of government activities and educational research, the use of information and communication technology (ICT) in teaching and 
learning stays just partially comprehended by educationalists and inconsistently practiced in universities [2].

Utilizing technology has become influential in the field of education, especially in the EFL context. In support of this view, Traxler [3] shed light on the definitions of mobile learning saying that the rapid progress of communication technological devices has revolutionized the learning process in general and the ESL learning in particular. Traxler's study provides evidence that mobiles should be exploited as an integrated component in the learning process. However, there are major obstacles to the effective implementation of MALL, in particular, how best to integrate MALL into other established educational technologies and teaching aids. The main challenge for MALL practitioners and researchers consists in finding an optimal balance between inward-facing teaching practice development and outward-facing contextualization, implementation and promotion of these practices.

Overall, smartphones are found to be more effective than traditional teaching tools and widely-used as they promote the use of technology in the classroom. Smartphones are handheld devices acting as combination of a traditional mobile phone and of a personal computer [4]. With internet connectivity, they can offer wide range of activities for language learners. There is a significant amount of literature on the impact of these devices on teachers as well as learners [5], [6], [7].

Further studies explored the impact of several variables on MALL. Sung, Chang and Liu [8] conducted a meta-analysis of the impact of mobile devices on teaching and learning by synthesizing 110 articles appearing between 1993 and 2013. They reported that there was a moderate mean effect size of 0.523 for the application of mobile devices to education. Kondo, Ishikawa, Smith, Sakamoto, Shimomura, and Wada [9] examined the effect of MALL on students' scores on listening and reading tests in Japan. They concluded that "features of self-study in the MALL group were stronger than in the control group, on average, in terms of time spent on learning tasks, levels of satisfaction derived from the tasks, and self-measured achievement" [9: 185]. They also emphasized that, in addition to developing self-regulated learning, MALL helped students not only improve their English but also their self-efficacy. In an attempt to improve students' English proficiency and decrease the achievement gap, Hung, Young and Lin [10] implemented a game-based learning activity called 'the Wireless Crossword Fan-Tan Game system' utilizing tablets. The findings showed that this collaborative and competitive game contributed to closing the achievement gap and produced better learning, interaction and effectiveness. All these studies demonstrated the positive impact of digital learning on achievement and revealed promising effects on facilitating learning more generally.

Some handheld devices such as tablet PCs require teacher training in order to be utilized effectively in the EFL context. Though teachers may encounter difficulty in the initial stage of implementing tablet PCs in classroom practice, they have been found to be user-friendly and to impact learners' performance positively. For instance, Çelik and Aytn [11] showed that while some Turkish EFL teachers have the required confidence in and positive attitude towards implementing digital tools in their classes, limited access to computers and the internet hinder them from making use of the available digital tools in their classes. Savas [12] investigated EFL teachers' perceptions of the 
effectiveness of tablet PCs as instructional tools in EFL classes in a Turkish university. The study was conducted over the course of one academic semester. The results of the study showed that EFL teachers have increasingly positive attitudes towards the use of tablet PCs as they become more experienced in using them for instructional purposes. Technical problems represented the main obstacle for EFL teachers. The study suggested that the EFL teachers should be given training sessions in order to master the use of such devices. This implies that tablet PCs can be utilized more effectively in developing the students' writing skills through providing access to a broader range of tasks, materials and applications.

Previous literature has researched the efficacy of utilizing technology on learners' receptive and productive skills. Al-Ruwaili [13], as an illustration, investigated the effects of smart devices on learners' performance. Data were collected from 500 teachers who responded to a questionnaire. The findings indicated that smart devices were most often used to develop listening skills and least often to develop writing skills. Moreover, there were no significant differences in enhancing language skills gender, school type and the teacher's level of experience.

Two areas of current research interest are the availability of smart devices in the EFL classroom and the effect of teacher training on uptake of smart device use. Merc [14] investigated to what extent teachers use modern technology in their classrooms. In his study, data were collected via a questionnaire and semi-structured interviews from 86 and 12 teachers respectively. The findings indicated that schools were not wellequipped with technological devices. Moreover, teachers were not keen on using the available technological tools in schools in their teaching practice. In addition, there was no integration between the teachers' training programs and the use of technology in EFL classes. Chen [15] investigated perceived perceptions and perceived acceptance of mobile learning (M-learning) by university EFL instructors and students. The participants were Taiwanese university students. The results of the questionnaire conducted in the study showed that the instructors and the students strongly supported the use of mobile phones for learning purposes. Yet, it is worth mentioning that the younger instructors had higher appreciation, support and acceptance of M-learning. The study strongly recommended the inclusion of M-learning and urged EFL educators to integrate it into their classrooms.

Dashtestani [16] investigated perceptions and attitudes of Iranian university students and their effect on the implementation of MALL. Although the results showed that Iranian EFL students are generally positive about the use of mobile devices for EFL learning, there were many barriers that hinder the effective implementation of MALL in EFL classrooms. One reason is that Iranian students seemed to be reluctant to accept any kind of imposition from their teachers. Another issue was the high cost of mobile devices for the majority of the students in this educational context. Further obstacles were students' ignorance of mobile phone learning and software applications. Therefore, the study recommended several changes to EFL curricula to meet the students' needs and expectations. In order to achieve the best results from MALL, TEFL providers need to: (1) promote knowledge of using mobile devices; (2) promote awareness about EFL software tools; (3) ensure adequate ICT infrastructure, such as highspeed Internet connections; (4) train EFL teachers to be more tolerant of mobile phone use in the 
classroom; and (5) encourage students' use of mobile phones inside the EFL classrooms. In short, teachers should be allowed and encouraged to play the role of the coordinator, instructor and facilitator.

Taj et al. [17] produced a meta-analysis of 13 studies published between 2008 and 2015 on the impact of using mobile phones in EFL classrooms. Focusing on the emergence of MALL, the study found that "intervention through mobile phones helps in EFL learning" and is "an important tool for vocabulary instruction" [17: 81]. Overall, the findings of the study strongly confirmed the efficacy of integrating MALL into EFL instructional practice.

Lee [21] investigated the influence of socio-cultural characteristics of teachers and students in the United States and South Korea on MALL effectiveness and instruction, and how MALL characteristics and preferences in MALL learning styles are closely connected with the development and implementation of MALL instruction. He conducted a survey of 259 participants and conducted 8 interviews in order to explore the participants' perceptions about MALL. The study showed that ESL teachers and students have a stronger belief in the effectiveness of MALL than do EFL teachers and students.

In summary, previous studies concerning the use of technology in EFL classes revealed that educational institutions such as universities and schools were often not wellequipped with suitable technological resources for implementation of MALL in classes [13], [14]. In addition, teachers were often reluctant to use or implement available devices in their classes [5], [14], [11]. Finally, there tended to be a mismatch between the MALL implementation training programs directed towards teachers and the support provided by educational institutions to facilitate implementation of and increased competence with the technology in question [13], [5], [14], [11].

Since the use of these devices is so widespread and a part of everyday life it is natural that mobile devices are part of the education process. Even if there is a growing consensus on the utility of integrating these devices into classroom, how this consensus manifests itself in the practice of educational systems remains an open question. The current study is designed to provide clear evidence for the extent of the usage of handheld devices by EFL teachers in the context of a university in the Kingdom of Saudi Arabia. The study focusses on the EFL teachers' perceptions of using handheld devices for educational purposes in the classroom, and the challenges they identify in trying to achieve successful implementation of MALL.

\section{Research Design}

The present study employed a mixed method approach in data collection. The first main instrument of research was a survey. Data were collected through a questionnaire distributed to 127 English teachers to find what type of smart handheld devices they used in class and to what extent they used smart handheld devices in teaching English. The questionnaire was composed of 13 items built over a five-Likert scale. These items represented possible functions for using smart handheld devices in teaching English. The second part of the study employed a qualitative approach in which data was 
collected through one-to-one interviews through open-ended questions (see Appendices 7.1 interview questions and 7.2 teachers' perceptions). The questions were designed to elicit data related to whether the participants were for or against using smart handheld devices in teaching English and why they held this view. It also allowed the participants to express their opinions regarding barriers that may hinder using smart handheld devices in classroom teaching and suggestions to overcome the barriers that hinder using smart handheld devices in classroom teaching.

\subsection{Participants}

The participants in this study comprised 127 English teachers at Imam Abdulrahman Bin Faisal University, Saudi Arabia. They were distributed as follows: 41 male teachers $(32 \%)$ and 86 female teachers $(68 \%)$ teaching single-sex male and female classes respectively. The number of native English-speaking teachers was $19(15 \%)$ and the number of non-native English teachers was 108 (85\%). The survey allowed categorization of teachers according to years of teaching experience as follows: 8 teachers had two years of experience or less, 18 teachers had between 3- and 5-years' experience, 37 teachers 6 to 10 years and 64 teachers more than 10 years. Table 1 illustrates the distribution of the participants according to gender, experience and whether they self-reported as native or non-native speakers of English.

Table 1. Demographic characteristics of participants

\begin{tabular}{|l|c|c|}
\hline \multicolumn{1}{|c|}{ Demographic Factors } & Number & Percentage \\
\hline Gender & 41 & $32.28 \%$ \\
\hline Male & 86 & $67.72 \%$ \\
\hline Female & 19 & $14.96 \%$ \\
\hline English is taught by & 108 & $85.04 \%$ \\
\hline Native speakers & 8 & $6.30 \%$ \\
\hline Non-native speakers & 18 & $13.17 \%$ \\
\hline Experience & 37 & $29.13 \%$ \\
\hline 2 years \& less & 64 & $50.39 \%$ \\
\hline $3-5$ years & 127 & \\
\hline $6-10$ years & & \\
\hline More than 10 years & \multicolumn{2}{|c|}{} \\
\hline Total & & \\
\hline
\end{tabular}

\section{$3 \quad$ Findings}

To answer the first question of the study related to the extent of using smart handheld devices in teaching English, participants answered a 5-Likert scale questionnaire. The findings revealed that 44 teachers (34\%) reported never using Android operating system phones in teaching English, 16 teachers (12\%) rarely, 29 teachers $(22 \%)$ sometimes, 17 teachers $(13 \%)$ frequently and 21 teachers (16\%) always. Therefore, only a minority of teachers (29\%) tended to use Android phones on a regular basis in the classroom. 48 teachers $(37 \%)$ reported never using iPhones (iOS operating system) in 
teaching English, 15 teachers (11\%) rarely, 29 teachers (23\%) sometimes, 16 teachers (12\%) frequently, and 19 teachers $(14 \%)$ always. Therefore, only a minority of teachers $(26 \%)$ tended to use iPhones in teaching on a regular basis.

Regarding Android tablets, 77 teachers $(60 \%)$ never used them in teaching English, 17 teachers $(13 \%)$ rarely, 25 teachers $(19 \%)$ sometimes, 6 teachers $(4 \%)$ frequently, and only 2 teachers (2\%) always. Therefore, the vast majority tended never to use Android tablet in teaching. 76 teachers $(59 \%)$ reported never using iPads (iOS operating system) in teaching English, 17 teachers (14\%) rarely, 22 teachers (17\%) sometimes, 9 teachers $(7 \%)$ frequently, and 3 teachers $(2 \%)$ always. Therefore, the majority tended never to use iPads (iOS System) in teaching. The participants were asked if they used any other devices which were not mentioned in the questionnaire and a majority of 69 teachers (54\%) never used any other devices in teaching English.

Although not too many participants employed technology in teaching, it was found that teachers with less teaching experience were more open to using technical devices in the classroom. It seems teachers with less teaching experience are younger and therefore more 'tech savvy' than their counterparts.

To sum up, the majority of teachers tended to use smart handheld devices in teaching English either never, rarely or sometimes. A large plurality of teachers reported never using Android tablets, iPads or any other tablet devices. This finding suggests that teachers still prefer to avoid integrating technology in their classes. Table (2) illustrates participants' reported frequency of use of smart handheld devices in teaching English.

Table 2. Reported frequency of classroom use of smart handheld devices by EFL teachers at IAU

\begin{tabular}{|c|c|c|c|c|c|c|c|}
\hline $\begin{array}{c}\text { Type of smart handheld } \\
\text { device }\end{array}$ & Never (1) & Rarely (2) & \begin{tabular}{|c|} 
Sometimes \\
(3)
\end{tabular} & \begin{tabular}{|c|} 
Frequently \\
(4)
\end{tabular} & Always (5) & Mean & SD \\
\hline \multirow{2}{*}{ Android phone } & 44 & 16 & 29 & 17 & 21 & \multirow{2}{*}{2.65} & \multirow{2}{*}{1.48} \\
\hline & $34.65 \%$ & $12.60 \%$ & $22.83 \%$ & $13.39 \%$ & $16.54 \%$ & & \\
\hline \multirow{2}{*}{ iPhone (iOS) } & 48 & 15 & 29 & 16 & 19 & \multirow{2}{*}{2.55} & \multirow{2}{*}{1.47} \\
\hline & $37.80 \%$ & $11.81 \%$ & $22.83 \%$ & $12.60 \%$ & $14.96 \%$ & & \\
\hline \multirow{2}{*}{ Android tablet } & 77 & 17 & 25 & 6 & 2 & \multirow{2}{*}{1.73} & \multirow{2}{*}{1.03} \\
\hline & $60.63 \%$ & $13.39 \%$ & $19.69 \%$ & $4.72 \%$ & $1.57 \%$ & & \\
\hline \multirow{2}{*}{ iPad (iOS) } & 76 & 17 & 22 & 9 & 3 & \multirow{2}{*}{1.78} & \multirow{2}{*}{1.11} \\
\hline & $59.84 \%$ & $13.39 \%$ & $17.32 \%$ & $7.09 \%$ & $2.36 \%$ & & \\
\hline \multirow{2}{*}{ Another tablet device } & 69 & 19 & 18 & 10 & 11 & \multirow{2}{*}{2.01} & \multirow{2}{*}{1.33} \\
\hline & $54.33 \%$ & $14.96 \%$ & $14.17 \%$ & $7.87 \%$ & $8.66 \%$ & & \\
\hline
\end{tabular}

To answer the question of what type purposes EFL teachers used handheld devices for, participants answered on a 5-likert scale questionnaire related to the types of activities, practices and functions that handheld devices were used for in teaching English at their institution. The findings revealed that $37 \%$ of teachers never used handheld devices to teach reading and its subskills, such as scanning and skimming. Teachers used these devices to teach various writing skills such as types of writing styles $10 \%, 21 \%$ for listening skills, $11 \%$ for grammar and tenses and $10 \%$ for educational games.

A significant proportion of teachers (30\%) reported sometimes using English-language learning and teaching applications, assigning online exercises and sharing 
information about the course. The results revealed that $27 \%$ of the participants claimed to use these devices to provide visual aids when teaching always. Additionally, $22 \%$ of the teachers claimed they always used them to teach speaking skills, such as pronunciation, or to translate from Arabic to English or vice-versa. Many participants always depended on handheld devices to teach vocabulary such as looking up words or checking spelling (34\%) and to provide visual aids when teaching (21\%). Finally, a large proportion of respondents tended always to communicate with students via social networks $(30 \%)$ and to use mobile devices to access textbooks (33\%).

This study shows that the use of a particular device and operating system was correlated with the gender of the teacher. A chi-square test was performed to test statistical significance as shown in Table 3. It was found that there were statistically-significant differences in the mean scores of male and female teachers in terms of their use of different operating systems. As shown in Table 3, the mean score for use of Android system phones for male teachers $(M=3.05, S D=1.944)$ was higher than the mean of female teachers $(\mathrm{M}=1.444, \mathrm{SD}=2.45)$. The mean score for using $\mathrm{iOS}$ phones for female teachers $(\mathrm{M}=2.88, \mathrm{SD}=1.529)$ was higher than that of male teachers $(\mathrm{M}=1.85$, $\mathrm{SD}=1.062)$. The results further show that the mean score for using iOS tablets for female teachers $(\mathrm{M}=1.98, \mathrm{SD}=1.188)$ was higher than that of male teachers $(\mathrm{M}=1.39$, $\mathrm{SD}=.802)$. Furthermore, the mean score for using other tablet type devices for female teachers $(M=2.16, S D=1.405)$ was higher than that of male teachers $(M=1.71$, $\mathrm{SD}=$.1.146). By contrast, there was no significant difference in the mean scores for using Android tablets.

Table 3. Results for use of smart handheld devices in teaching English across gender groups

\begin{tabular}{|c|c|c|c|c|c|c|c|}
\hline Operating System & Gender & $\begin{array}{c}\text { Mean Lik- } \\
\text { ert Score }\end{array}$ & Std. Deviation & $\mathbf{t}$ & $\begin{array}{c}\text { Mean Dif- } \\
\text { ference }\end{array}$ & $\begin{array}{l}\text { Std. Error } \\
\text { Difference }\end{array}$ & sig \\
\hline \multirow{2}{*}{$\begin{array}{l}\text { Android operating sys- } \\
\text { tem phone }\end{array}$} & Male & 3.05 & 1.499 & \multirow{2}{*}{2.145} & \multirow{2}{*}{.595} & \multirow{2}{*}{.277} & \multirow{2}{*}{$.034 *$} \\
\hline & Female & 2.45 & 1.444 & & & & \\
\hline \multirow{2}{*}{ iOS phone } & Male & 1.85 & 1.062 & \multirow{2}{*}{-3.885} & \multirow{2}{*}{-1.030} & \multirow{2}{*}{.265} & \multirow{2}{*}{$.000 *$} \\
\hline & Female & 2.88 & 1.529 & & & & \\
\hline \multirow{2}{*}{ Android tablet } & Male & 1.73 & .837 & \multirow{2}{*}{-.004} & \multirow{2}{*}{-.001} & \multirow{2}{*}{.197} & \multirow{2}{*}{.997} \\
\hline & Female & 1.73 & 1.121 & & & & \\
\hline \multirow{2}{*}{ iOS tablet } & Male & 1.39 & .802 & \multirow{2}{*}{-2.862} & \multirow{2}{*}{-.587} & \multirow{2}{*}{.205} & \multirow{2}{*}{$.005^{*}$} \\
\hline & Female & 1.98 & 1.188 & & & & \\
\hline \multirow{2}{*}{$\begin{array}{l}\text { Another tablet type de- } \\
\text { vice }\end{array}$} & Male & 1.71 & 1.146 & \multirow{2}{*}{-1.808} & \multirow{2}{*}{-.455} & \multirow{2}{*}{.252} & \multirow{2}{*}{.073} \\
\hline & Female & 2.16 & 1.405 & & & & \\
\hline
\end{tabular}

The second part of the study demonstrates qualitative findings collected through oneto-one interviews. To answer whether the participants were for or against using smart handheld devices in teaching English and their reasons for their position, 110 participants reported being for it while only 17 were against. The responses of the participants are anonymous. The participants gave the following reasons in support of the use of smart handheld devices in teaching English: enhancing teaching and learning processes, motivating students, facilitating the learning process, creating joyful learning, responsiveness to the diversity of learner levels, saving time and effort for both teachers and 
learners, and promoting innovation and creativity. Handheld devices can provide access to reliable sources of information. Moreover, the advocates of the use of these devices say that they increase students' self-dependency, autonomy and self-confidence. This finding is consistent with Ushioda's view [18] that autonomy and motivation are closely connected. If the learners are motivated to use these devices, they will be more likely to achieve a considerable level of autonomy.

Table 4. Functions of using handheld devices in teaching English

\begin{tabular}{|c|c|c|c|c|c|c|c|}
\hline & Never (1) & Rarely (2) & $\begin{array}{c}\text { Sometimes } \\
\text { (3) } \\
\end{array}$ & \begin{tabular}{|c|} 
Frequently \\
$(4)$
\end{tabular} & Always (5) & Mean & SD \\
\hline \multirow{2}{*}{$\begin{array}{l}\text { Teach reading, such as } \\
\text { scanning and skimming. }\end{array}$} & 47 & 15 & 35 & 20 & 10 & \multirow{2}{*}{2.45} & \multirow{2}{*}{1.33} \\
\hline & $37.01 \%$ & $11.81 \%$ & $27.56 \%$ & $15.75 \%$ & $7.87 \%$ & & \\
\hline \multirow{2}{*}{$\begin{array}{l}\text { Teach writing, such as a } \\
\text { range of writing styles. }\end{array}$} & 43 & 20 & 26 & 25 & 13 & \multirow{2}{*}{2.56} & \multirow{2}{*}{1.39} \\
\hline & $33.86 \%$ & $15.75 \%$ & $20.47 \%$ & $19.69 \%$ & $10.24 \%$ & & \\
\hline \multirow{2}{*}{$\begin{array}{l}\text { Teach listening, such as } \\
\text { listening skills. }\end{array}$} & 37 & 14 & 27 & 22 & 27 & \multirow{2}{*}{2.90} & \multirow{2}{*}{1.51} \\
\hline & $29.13 \%$ & $11.02 \%$ & $21.26 \%$ & $17.32 \%$ & $21.26 \%$ & & \\
\hline \multirow{2}{*}{$\begin{array}{l}\text { Teach speaking, such as } \\
\text { pronunciation. }\end{array}$} & 26 & 7 & 38 & 28 & 28 & \multirow{2}{*}{3.19} & \multirow{2}{*}{1.39} \\
\hline & $20.47 \%$ & $5.51 \%$ & $29.92 \%$ & $22.05 \%$ & $22.05 \%$ & & \\
\hline \multirow{2}{*}{$\begin{array}{l}\text { Teach vocabulary, such as } \\
\text { looking up words or check- } \\
\text { ing spelling. }\end{array}$} & 9 & 10 & 32 & 33 & 43 & \multirow[b]{2}{*}{3.71} & \multirow[b]{2}{*}{1.21} \\
\hline & $7.09 \%$ & $7.87 \%$ & $25.20 \%$ & $25.98 \%$ & $33.86 \%$ & & \\
\hline \multirow{2}{*}{$\begin{array}{l}\text { Teach grammar, such as } \\
\text { tenses. }\end{array}$} & 39 & 16 & 33 & 25 & 14 & \multirow{2}{*}{2.67} & \multirow{2}{*}{1.37} \\
\hline & $30.71 \%$ & $12.60 \%$ & $25.98 \%$ & $19.69 \%$ & $11.02 \%$ & & \\
\hline \multirow{2}{*}{$\begin{array}{l}\text { Communicate with stu- } \\
\text { dents via social networks. }\end{array}$} & 23 & 10 & 23 & 32 & 39 & \multirow{2}{*}{3.42} & \multirow{2}{*}{1.45} \\
\hline & $18.11 \%$ & $7.87 \%$ & $18.11 \%$ & $25.20 \%$ & $30.71 \%$ & & \\
\hline \multirow{2}{*}{$\begin{array}{l}\text { Play educational/ } \\
\text { language games. }\end{array}$} & 25 & 19 & 41 & 29 & 13 & \multirow{2}{*}{2.89} & \multirow{2}{*}{1.25} \\
\hline & $19.69 \%$ & $14.96 \%$ & $32.28 \%$ & $22.83 \%$ & $10.24 \%$ & & \\
\hline \multirow{2}{*}{$\begin{array}{l}\text { Use English-language } \\
\text { learning and teaching ap- } \\
\text { plications. }\end{array}$} & 23 & 17 & 42 & 22 & 23 & \multirow[b]{2}{*}{3.03} & \multirow[b]{2}{*}{1.33} \\
\hline & $18.11 \%$ & $13.39 \%$ & $33.07 \%$ & $17.32 \%$ & $18.11 \%$ & & \\
\hline \multirow{2}{*}{$\begin{array}{l}\text { Assign online exercises/in- } \\
\text { formation about the course. }\end{array}$} & 18 & 17 & 39 & 20 & 33 & \multirow{2}{*}{3.26} & \multirow{2}{*}{1.35} \\
\hline & $14.17 \%$ & $13.39 \%$ & $30.71 \%$ & $15.75 \%$ & $25.98 \%$ & & \\
\hline \multirow{2}{*}{ Access the textbook. } & 31 & 13 & 30 & 11 & 42 & \multirow{2}{*}{3.15} & 1.57 \\
\hline & $24.41 \%$ & $10.24 \%$ & $23.62 \%$ & $8.66 \%$ & $33.07 \%$ & & | \\
\hline Translate texts/words from & 29 & 26 & 38 & 16 & 18 & & \\
\hline $\begin{array}{l}\text { Arabic to English and vice } \\
\text { versa. }\end{array}$ & $22.83 \%$ & $20.47 \%$ & $29.92 \%$ & $12.60 \%$ & $14.17 \%$ & 2.74 & 1.32 \\
\hline Provide visual aids when & 25 & 10 & 27 & 30 & 35 & 3.31 & 1.45 \\
\hline teaching. & $19.69 \%$ & $7.87 \%$ & $21.26 \%$ & $23.62 \%$ & $27.56 \%$ & דונ. & $1.4 J$ \\
\hline
\end{tabular}

The statistics in tables 2 and 4 indicate a high level of internal consistency, as evidenced by a high Cronbach's alpha coefficient ( 13 items; $\alpha=.90)$. This estimate suggests that the questionnaire items produced very reliable data, and the data collected using this instrument were sufficiently internally-consistent for the purpose of further analysis in the present research. 
Table 5. Internal consistency as measured by Cronbach's Alpha

\begin{tabular}{|c|c|}
\hline $\mathbf{N}$ (number of items) & Cronbach's Alpha \\
\hline 13 & .902 \\
\hline
\end{tabular}

In addition, the results of this study show that teachers believe that mobile learning boosts students' happiness and motivation. This corroborate other findings such as Baydas and Yilmaz [19], Jones et al. [20], Lee [21], Ockert [22], and Stockwell [18]. In terms of vocabulary learnability, the findings of the study supported Hamalis' proposal [5] that electronic devices help students in understanding vocabulary. Vocabulary applications can provide a wide range of synonyms and antonyms and explain the meaning of a word in various ways.

However, the participants who expressed opposition to using smart handheld devices in teaching English provided the following reasons: cultural acceptability of their use in Saudi society, complications of using the devices, e-podium availability in classrooms, and difficulty in controlling students using their mobiles in classrooms. These reasons were given previously by Dashtestani [16], whose study reported that technology may hinder learning if students lack awareness of smartphone applications or access to the Internet. Furthermore, technology needs extensive training, and often expensive software applications are required. Some teacher participants at IAU also added that devices can cause a distraction and make it almost impossible to guide or control the students inside the classroom. According to their comments generated by the survey, they highlighted that the use of these devices increases students' laziness.

The qualitative data was collected through one-to-one interviews and participant responses transcribed into a word-processing document for further analysis. The results and information obtained from the interviews were categorized thematically based on similarities of the answers given by the participants. The findings indicated that there were many barriers hindering the use of smart handheld devices in classroom teaching, such as: (1) poor internet connectivity; (2) the type of devices teachers owned; (3) lack of proper technical support; and (4) difficulty in monitoring the students' usage of the devices [16]. The first finding is consistent with Çelik's and Aytn's study [11], which also found internet connectivity to be a serious issue. Access to smart devices in the classroom causing distraction has also been mentioned in the research literature [7]. It was also mentioned by some participants that the target skill may make it difficult to learn by means of handheld smart devices. Two other negative contributing factors which were mentioned by the participants, namely the high cost to teachers and students and time constraints, are consistent with Dashtestani's findings [16].

The majority of respondents indicated that the main barriers hindering using smart handheld devices in classroom teaching are inadequate infrastructure and the devices' potential for distraction. The barrier which was mentioned most often was the limiting effect of using handheld devices on direct interaction between the students and the teacher. During the interviews, participants were asked to propose suggestions to overcome the barriers that hinder using smart devices in classroom teaching. After classifying and categorizing the data, the findings revealed that the following suggestions may be applied to overcome barriers that hinder using smart handheld devices in classroom teaching: (1) technical assistance and support during the classes must be available; (2) 
all sources of distractions such as social media must be blocked during the classes; (3) teachers must manage the use of devices in a professional manner; and (4) educational institutions must provide links, applications, materials and activities designed specifically for use on these devices.

\section{Conclusion}

The findings of this study suggest that, despite the great potential benefits of handheld devices for language learning, teachers have mixed feelings when it comes to the usage of these devices for teaching purposes. As the data suggest, teachers tend to use handheld devices in a limited way in terms of frequency of use and the range of purposes to which these devices are put. Teachers tend to use the devices as a dictionary or a tool to show supporting visuals for their conventional teaching, but avoid using them extensively while teaching skills such as reading, or writing. Qualitative data showed that there are multiple issues discouraging teacher from integrating these devices into their practices to a greater extent.

The interviews with the teachers revealed that the majority of the issues observed or expected by the teachers regarding the usage of handheld devices are related to monitoring student usage and maintaining discipline. However, they also stated some technical shortcomings, like connection issues and technical support. It can be argued that teachers are concerned with the misuse of the technology, and that there is a stigma among the teachers regarding the extensive usage of these devices, namely, beyond using them to access well-accepted resources such as dictionary applications, textbooks, and online encyclopedias. The suggestions given regarding blocking social media and some other functions of the handheld devices support the claim that teachers are not considering these tools primarily as teaching tools but rather as potential disruptors to effective classroom dynamics. It is hoped that the challenges and negative perceptions regarding the use handheld devices can be overcome with training and support so that the potential of these devices can be used for more effective teaching and producing more authentic language use in the language classroom.

\section{$5 \quad$ Recommendations for Future Research}

In order to identify further obstacles to the effective implementation of MALL relating to time and classroom management, it is recommended for future studies to pilot EFL courses which fully-integrate handheld device usage into the syllabus so that their effectiveness can be measured against existing classroom practices. In short, the comparison between two different modes of delivering the same course may clarify whether learners who make extensive use of handheld devices outperform their counterparts or not. Future studies within the scope of this research area may also benefit from utilizing the observation tools used here to measure to what extent teachers really use smart devices in teaching. In this study, the quantitative data indicated that the majority of teachers did not use smart handheld devices in classroom teaching, while the interview responses indicated that the majority were using smart handheld devices in classroom 
teaching. This suggests that teachers are likely to ignore or misrepresent the extent to which they promote smart handheld device use in their classrooms, and the need for mixed methodologies research.

\section{References}

[1] C. Wu Cheng, "Using handhelds in a Jigsaw cooperative learning environment," Journal of Computer Assisted Learning, vol. 22, no. 4, pp. 284-297, 2006. https://doi.org/10.1111/ j.1365-2729.2006.00176.x

[2] G. Goldstein, Information technology in English schools: A commentary on inspection findings, Coventry: NCET/OFSTED, 1997.

[3] J. Traxler, "Learning in a mobile age," International Journal of Mobile and Blended Learning, vol. 1, no. 1, pp. 1-12, 2009.

[4] A. T. Korucu and A. Alkan, "Differences between m-learning (mobile learning) and e-learning, basic terminology and usage of m-learning in education," Procedia-Social and Behavioral Sciences, vol. 15, pp. 1925-1930, 2011. https://doi.org/10.1016/j.sbspro.2011. $\underline{04.029}$

[5] M. Hamalis, "The effect of smart devices on learning English vocabulary and reading among English majors at Al-Hussein Bin Talal University,” M.S. thesis, Mutah University, Jordan, 2015.

[6] C. Marcelo, C. Yot and C. Mayor, "University teaching with digital technologies," Comunicar, vol. 45 , no. 23 , p. 117-124.

[7] B. R. McCoy, "Digital distractions in the classroom phase II: Student classroom use of digital devices for non-class related purposes," 17 May 2016. [Online]. Available: https://digitalcommons.unl.edu/cgi/viewcontent.cgi?article=1091\&context=journalismfacpub. $[$ Accessed May 17, 2020].

[8] Y. T. Sung, K. E. Chang and T. C. Liu, "The effects of integrating mobile devices with teaching and learning on students' learning performance: A meta-analysis and research synthesis," Computers \& Education, vol. 94, pp. 252-275, 2016. https://doi.org/10.1016/ j.compedu.2015.11.008

[9] M. Kondo, I. Yasushige, C. Smith, K. Sakamoto, H. Shimoura and N. Wadn, "Mobile assisted language learning in university EFL courses in Japan: Developing attitudes and skills for self-regulated learning," ReCALL, vol. 24, no. 2, pp. 169-187, 2012. https://doi.org/10. $\underline{1017 / \mathrm{s} 0958344012000055}$

[10] Hui-Chun Hung, Shelley Shwu-Ching Young and Chiu-Pin Lin, "No student left behind: a collaborative and competitive game-based learning environment to reduce the achievement gap of EFL students in Taiwan," Technology, Pedagogy and Education, vol. 24, no. 1, pp. 35-49. https://doi.org/10.1080/1475939x.2013.822412

[11] S. Çelik and K. Aytın, "Teachers' views on digital educational tools in English language learning: Benefits and challenges in the Turkish context," The Electronic Journal for English as a Second Language, vol. 18, no. 2, pp. 1-18, 2014.

[12] P. Savas, "Tablet PCs as instructional tools in EFL education," Turkish Online Journal of Educational Technology-TOJET, vol. 13, no. 1, pp. 217-222.

[13] D. Halvoník and J. Kapusta, "Framework for e-Learning materials optimization," International Journal of Emerging Technologies in Learning (iJET), vol. 15, no. 11, 2020. https://doi.org/10.3991/ijet.v15i11.12721 
[14] A. Al-Ruwaili, "The role of smart tablets devices in the development of English language skills for secondary school students in Saudi Arabia from teachers' point of view," M. S. thesis, Yarmouk University, Jordan, 2015.

[15] A. Merc, "Using technology in the classroom: A study with Turkish pre-service EFL teachers," Turkish Online Journal of Educational Technology-TOJET, vol. 14, no. 2, pp. 229240, 2015.

[16] K. Chen, Examining EFL instructors' and students' perceptions and acceptance toward MLearning in higher education, Verlag, Berlin: Springer, 2016.

[17] B. K. Prahani, "Blended web mobile learning (BWML) model to improve students' higher order thinking skills," International Journal of Emerging Technologies in Learning (iJET), vol. 15, no. 11, 2020. https://doi.org/10.3991/ijet.v15i11.12853

[18] R. Dashtestani, Computer assisted language learning: Moving bravely towards mobile learning: Iranian students' use of mobile devices for learning English as a foreign language, United Kingdom: Routledge, 2016. https://doi.org/10.1080/09588221.2015.1069360

[19] L. Lin, "An evaluation system and its model for educational competitiveness of universities," International Journal of Emerging Technologies in Learning (iJET), vol. 15, no. 11.

[20] I. Taj, N. Sulan, M. Sibra and W. Ahmad, "Impact of mobile assisted languagelearning (MALL) on EFL: A meta-analysis," Advances in Language Literary Studies, vol. 7, no. 2, pp. 67-83, 2016. https://doi.org/10.7575/aiac.alls.v.7n.2p.76

[21] G. Stockwell, in International perspectives in motivation: Language learning and professional challanges, E. Ushioda, Ed., London, United Kingdom: Palgrave Macmillan, 2013, pp. 156-175.

[22] O. Baydas and R. M. Yilmaz, "Pre-service teachers' intention to adopt mobile learning: A motivational model," vol. 49, no. 1, pp. 137-152, 2018. https://doi.org/10.1111/bjet. $\underline{12521}$

[23] A. Jones, K. Issroff and S. E., "Affective factors in learning with mobile devices," in Big issues in mobile learning: Report of a workshop by the kaleidoscope network of excellence mobile learning initiative, M. Sharples, Ed., University of Nottingham, 2006, pp. 15-20.

[24] G. Lee, "Examining the impact of MALL integration on ESL and EFL teachers and students," PhD. thesis, California School of Education, Alliant International University, United States, 2019.

[25] D. Ockert, "Using a tablet computer for EFL positive self-review: Increases in self-determination theory-based learning motives," Computer Assisted Language Instructions Consortium, vol. 35, no. 2, pp. 182-199, 2018. https://doi.org/10.1558/cj.32185

\section{Author}

Dr. Sami Al-Mubireek has an MA in English as Second/Foreign Language and a $\mathrm{PhD}$ in Teaching English to Speakers of Other Languages (TESOL) from the Ohio State University, Columbus, Ohio, USA. He was the former Head of the English Language Department for more than five years at the University of Dammam. Currently, he is an assistant professor and the head of Studies and Research Unit, Preparatory Year Deanship at Imam Abdulrahman Bin Faisal University, Saudi Arabia. His recent publications appeared in the Computer-Assisted Language Learning Electronic Journal and in the Asian EFL Journal. Email: smubireek@iau.edu.sa

Article submitted 2020-06-28. Resubmitted 2020-07-31. Final acceptance 2020-07-31. Final version published as submitted by the authors. 


\section{$8 \quad$ Appendix}

\subsection{One to one interview questions}

Please answer the following questions:

1. Are you for or against using smart handheld devices in teaching English? What is the reason for your answer?

Opinion: I am for using handheld devices in teaching English.

$\operatorname{Reason}(\mathbf{s})$ :

Opinion: I am against using handheld devices in teaching English.

$\operatorname{Reason}(\mathbf{s})$ :

2. In your opinion, what are the barriers to using smart handheld devices in classroom teaching?

3. Write any additional information/comments would you like to add.

4. Thank you very much!

\subsection{Teachers' perceptions of the benefits of handheld devices}

1. I believe students' learning is enhanced during my class if mobile technologies are used.

2. I am willing to learn how to incorporate mobile technologies in my teaching.

3. Mobile technologies can help create learning opportunities for my students outside formal classes.

4. All students should have access to mobile technologies to support their formal and informal learning.

5. I believe using mobile technologies will enable students to become knowledge producers.

6. My faculty/department supports the use of mobile technologies for teaching and learning.

7. I believe incorporating mobile technologies into teaching can improve the quality of teaching programs at the university.

\subsection{Drawbacks}

1. I prefer students not to use mobile technologies in my class. I believe using mobile technologies makes students less critical in using information.

2. I believe using mobile technologies in my teaching will increase my workload. 